\title{
THE EFFECT OF INDIVIDUAL AND COMMUNITY ATTRIBUTES ON RESIDENTS' ATTITUDES TOWARD TOURISM-BASED DEVELOPMENT
}

\author{
Paul M. Jakus and Paul B. Siegel*
}

\begin{abstract}
Tourism is a popular regional development strategy with both positive and negative impacts. In this paper, ordered probit analysis is used to isolate individual and community attributes which influence residents' attitudes toward tourism. This approach can be used to help design an appropriate tourism-based development strategy for a given community.
\end{abstract}

\section{INTRODUCTION}

Tourism is an increasingly popular regional development strategy. In particular, many rural communities have looked to tourism as a path to economic development (Frederick 1993; Gibson 1993; Luloff et al. 1994). In considering tourism as a regional development strategy, however, the choices made by planning agencies can have both positive and negative aspects. Tourism can stimulate new businesses, create new jobs, increase tax revenues, and is often perceived as an environmentally clean growth industry requiring few public services. Others have argued that many tourism jobs are low-paying and seasonal, with few additional benefits; that tourism development can destroy the local culture, degrade the local natural environment, strain public services, increase the local cost of living, and cause conflicts among residents (Feuerstein and Feuerstein 1992; Frederick 1993; Gibson 1993). In addition, due to the evolutionary nature of tourism-based development, short-run private and public benefits may be countered by long-run costs (Fritz 1989).

For communities considering tourism development, it is important to assess the attitudes of residents because tourism-based development projects require the support of local residents. ${ }^{1}$ Alternative tourism-based development strategies will offer different combinations of positive and negative impacts, and the benefits and costs of tourism development will accrue to different individuals. In a portion of our study area, for example, all residents suffer from peak season traffic congestion, yet only a portion of the community benefits from the greater incomes resulting from tourism. A better understanding of the factors influencing residents'

\footnotetext{
*Assistant Professor, University of Tennessee; and Senior Lecturer, Tel Hai College. This research was supported by the Tennessee Agricultural Experiment Station, The Tennessee Valley Authority, and the Southern Appalachian Man and Biosphere Project. Senior authorship is shared.
} 
attitudes toward tourism will help planners and policymakers identify areas of consensus and conflict among residents and the types of tourism development that might be desired.

This paper contributes to the literature in two ways: First, we demonstrate that both individual- and community-level characteristics should be considered when assessing residents' attitudes. Most of the past literature has focused on one type of characteristic to the exclusion of the other. Second, we use ordered probit analysis to measure the statistical relationship between resident attitudes toward tourism development. Past studies have used a variety of methods-descriptive statistics, contingency analysis, analysis of variance or factor analysis-but the ordered probit methodology provides additional insight into the process because it can handle both discrete and continuous data. The approach presented in this paper can be used by planners and policymakers to anticipate resident attitudes toward different types of tourism development.

\section{ATTITUDES TOWARD TOURISM DEVELOPMENT: A BRIEF REVIEW}

Past studies of residents' attitudes toward tourism development indicate that differences in attitudes are correlated with both individual- and community-level characteristics (Allen et al., 1988; Long et al. 1990; Lankford and Howard 1994). The results for individual level attributes generally show that support for tourism development is positively related to an individuals' income and employment in the tourist sector. In contrast, affiliation with a conservation group has been negatively related with support for the tourism development. Length of tenure in the community also tends to be negatively correlated with support for tourism development.

With respect to community-level attributes, the median level of community income tends to be negatively related with support for certain types of tourism development. On the other hand, the extent of a community's economic dependence on tourism has been found to have a positive correlation with support for tourism development-up to a threshold level. A community's population growth rate has, in some cases, been found to be to be negatively related to support for tourism growth. Population growth can be considered a proxy for externalities, such as congestion, increased pressure on environmental quality, and community character. 


\section{STATISTICAL METHODS}

The results outlined above were based primarily on descriptive statistics, contingency analysis, analysis of variance, or factor analysis. These widely used approaches, however, provide limited information about individual characteristics influencing residents' attitudes and community attributes. Residents' attitudes toward tourism development are often measured using naturally ordered responses (e.g., $5=$ strongly agree, $4=$ agree, $3=$ uncertain, $2=$ disagree, or $1=$ strongly disagree), so that ordered probit analysis can be used to provide additional information on factors influencing residents' attitudes. ${ }^{2}$ The ordered probit model assumes that an individual's response is due to a unobserved latent variable, $y^{*}$, corresponding to the process,

$$
y^{*}=x \beta+\varepsilon
$$

where $y^{*}$ is the unobserved variable measuring preference intensity, $x$ is the vector of explanatory variables, and $\varepsilon$ is the random component. While the value of $y^{*}$ is unobserved, an individual's ordinal choice, $y$, is observed as a discrete survey response.

For example, suppose an individual is asked a question regarding the growth of tourism in the community: "Do you feel the tourism industry is growing too quickly, about right, or too slowly?" In essence, this question asks an individual to evaluate the impact of changes associated with tourism. An individual who perceives a negative impact might respond that tourism was growing "too quickly." Similarly, an individual experiencing small or moderate benefits might respond that tourism was growing "about right," while an individual who enjoys relatively large benefits might respond with "too slowly." Coding according to intensity of preference, where 0="Too Quickly", 1="About Right", and 2="Too Slowly", responses are observed as,

$$
\begin{aligned}
& y=0 \text { if } y^{*} \leq 0 \\
& y=1 \text { if } 0 \leq y^{*} \leq \mu_{1} \\
& y=2 \text { if } \mu_{1} \leq y^{*}
\end{aligned}
$$

where $\mu_{1}$ represents a threshold value for $y^{*}$ above or below which the individual will change the ordinal ranking. $\mu_{1}$ is estimated as a random variable along with the $\beta$ vector. ${ }^{3}$ Assuming $\varepsilon$ to be normally distributed, the probability of the response being in any ordinal category is given by, 


$$
\begin{aligned}
& P(y=0)=\phi(-x \beta) \\
& P(y=1)=\phi\left(\mu_{1}-x \beta\right)-\phi(-x \beta) \\
& P(y=2)=1-\phi\left(\mu_{1}-x \beta\right)
\end{aligned}
$$

where $\phi($.$) is the normal cumulative distribution. The likelihood function is$ formed from these probabilities, where the optimization routine selects the $\beta$ which maximizes the likelihood of observing the sample.

The coefficients from an ordered probit model do not generally have a simple interpretation (Greene 1992). When a single independent variable is changed, the probability of being in any given category is changed. Increasing (decreasing) the probability of one category means that at least one of the probabilities for another category must decrease (increase), since the sum of all probability changes must equal zero. While the marginal effects must be calculated to determine the impact on the middle categories, the change in the probability of the highest category (in this case, "Too Slowly") will be of the same sign as the coefficient, and the change in the probability of the lowest category ("Too Quickly") will be of the opposite sign. Because the change in the highest category is of the same sign as the coefficient, hypotheses about development policy impacts can be tested empirically. The presentation and discussion of results reflect the appropriate marginal effects calculations.

\section{STUDY AREA}

Tourism development has long been considered as a possible solution to problems of unemployment and low income in the Appalachian region (Raitz and Ulack 1984; Peine and Welch 1990). Six rural counties in the Southern Appalachian highlands-three in Tennessee (Blount, Cocke, Sevier) and three in North Carolina (Graham, Haywood, Swain)-were selected for this study because each is adjacent to the Great Smoky Mountains National Park and has potential for tourism development. ${ }^{4}$ The counties differ in terms of their socio-economic characteristics, tourist attractions, and the relative importance of tourism to the local economy (see Table 1). In general, the counties on the Tennessee side of the National Park experienced more rapid growth in population and employment than the North Carolina counties. Much of this growth can be attributed to increases in tourism associated with the National Park, the numerous theme parks and tourism-related services offered in Sevier and Blount counties. In contrast, the North Carolina counties experienced little or no growth in the 1980s. Each county has faced development choices which mirror those experienced in other parts of the country, with the political debate centering around the monetary benefits of 


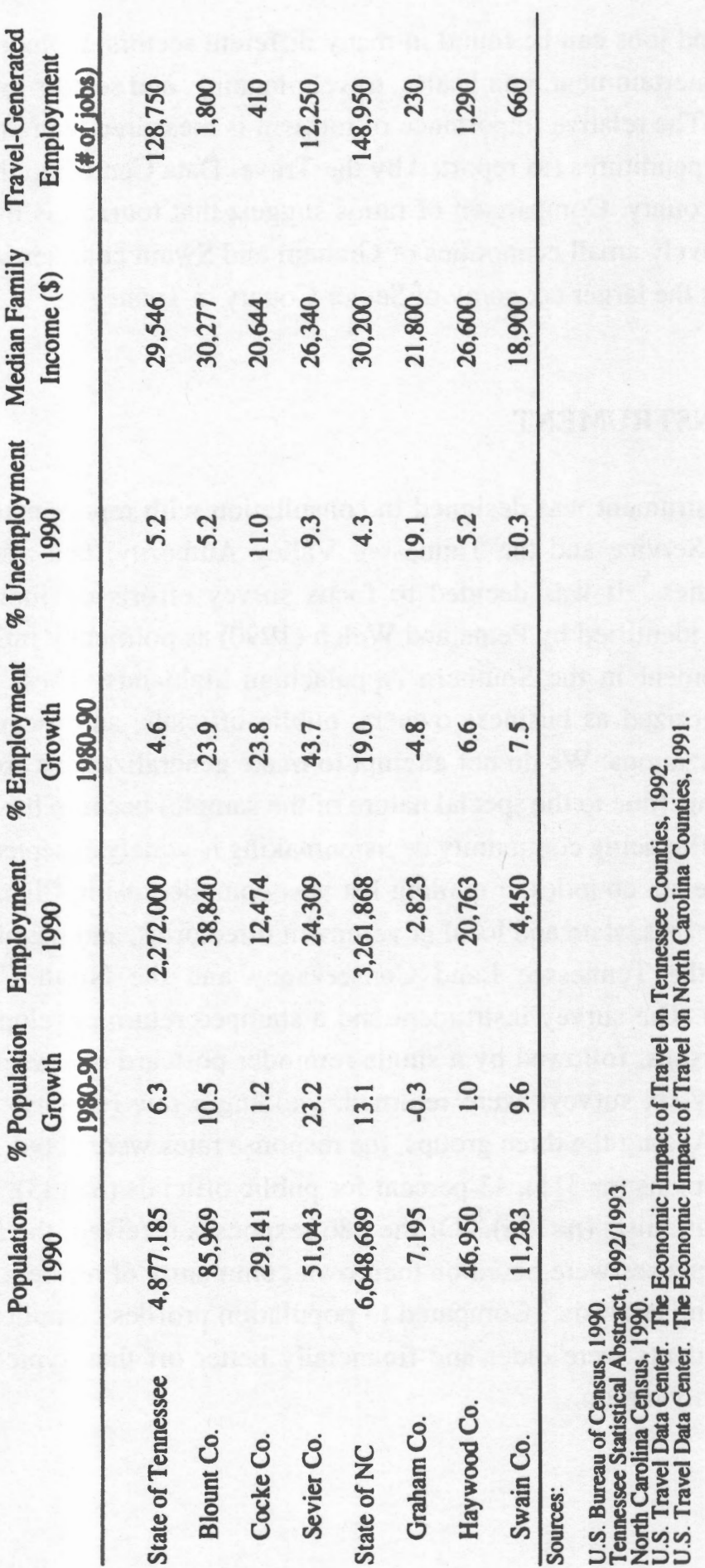


tourism development at the cost of losing the character and environmental quality of the community.

Tourism-related jobs can be found in many different sectors, including food service, lodging, entertainment, retail sales, travel planning, and sectors providing transport services. The relative importance of tourism is measured using the ratio of travel-related expenditures (as reported by the Travel Data Center) to the number of jobs in the county. Comparison of ratios suggest that tourism is more important to the relatively small economies of Graham and Swain counties in North Carolina, as well as the larger economy of Sevier County in Tennessee.

\section{SURVEY INSTRUMENT}

The survey instrument was designed in consultation with representatives of the National Park Service and the Tennessee Valley Authority, and also drew upon previous studies. ${ }^{5}$ It was decided to focus survey efforts on individuals drawn from groups identified by Peine and Welch (1990) as politically influential in tourism development in the Southern Appalachian highlands. These groups were broadly categorized as business owners, public officials, and members of conservation organizations. We do not attempt to make generalizations about the population as a whole (due to the special nature of the sample) because the central role of leaders in influencing community decisionmaking is widely accepted. ${ }^{6}$

For each of the six counties, a mailing list was compiled using Chamber of Commerce member lists, state and local government directories, and membership lists provided by the Tennessee Land Conservancy and the North Carolina Wildlife Federation. The survey instrument and a stamped return envelope were mailed to 1,454 persons, followed by a single reminder postcard one week later. Five hundred eighty-six surveys were returned, yielding a raw response rate of about 40 percent. ${ }^{7}$ Among the three groups, the response rates were about 35 percent for business persons $(n=315), 43$ percent for public officials $(n=133)$, and 54 percent for conservationists $(n=138) .{ }^{8}$ of the 586 responses received, the 529 individuals whose responses were based on their own community of residence were used for the following analysis. ${ }^{9}$ Compared to population profiles compiled from census data, respondents were older and financially better off than typical residents of the six-county region. 


\section{RESULTS}

Table 2 provides the names and definitions of variables used in the models and sources of the data. Ordered probit analysis was applied to four questions which reflect attitudes toward tourism development in general, trade-offs associated with tourism development, and future tourism development. The first two questions focus on past and present tourism development, while the second two questions focus on future tourism development. For each question, three policy models were specified. In the first model, a resident's attitudes were assumed to be a function of individual attributes only, while in the remaining two models, resident attitudes were assumed to be a function of both individual and community attributes. A likelihood ratio test was performed to test whether the addition of community-level attributes provide statistically different results from the model estimated, using only individual-level attributes. Results of the ordered probit analysis are presented in Tables 3 and 4 . The discussion focuses on statistically significant coefficients (at $=0.05$ and $=0.10$ levels) of these attributes.

\section{The Rate of Tourism Growth}

Individuals with higher incomes are more likely to respond that tourism is growing too slowly (Table 3 ). ${ }^{10}$ Thus, higher income individuals have fairly posi-

TABLE 2

Variable Names, Definitions, and Data Sources

Individual-Level Variables

Household Income (\$)

Member of Conservation Organization

Tourism-Related Job

Length of Residence

\section{Community-Level Variables}

County Median Income (\$) County Unemployment Rate (\%)

County Travel Expenditures per Job (\$/job)

Population Growth Rate (\%)
Data Sources

Estimated by grouped data model in

Appendix A (Survey)

$1=y e s, 0=$ no (Survey)

$1=y e s, 0=$ no (Survey)

Years lived in Southern Appalachians

divided by age (Survey)

1990 (Bureau of Census)

1990 (Bureau of Census)

Travel-generated expenditures in county

divided by number of jobs in county

(U.S. Travel Data Center, Bureau of

Census)

1980-1990 growth rate in incorporated areas (town-specific) or unincorporated (remainder of county, net of incorporated areas) (Bureau of Census) 
TABLE 3

Attitudes Toward Current Tourism Growth and Impacts

\begin{tabular}{|c|c|c|c|c|c|c|}
\hline \multirow{3}{*}{$\begin{array}{l}\text { Variable } \\
\text { Intercept }\end{array}$} & \multicolumn{3}{|c|}{ Question \#1 } & \multicolumn{3}{|c|}{ Question \#2 } \\
\hline & \multicolumn{3}{|c|}{$\begin{array}{l}\text { Do you feel the tourism industry in this } \\
\text { community is growing too slowly, about } \\
\text { right, or too quickly? }\end{array}$} & \multicolumn{3}{|c|}{$\begin{array}{l}\text { Tourism increases the quality } \\
\text { of life in this community. }\end{array}$} \\
\hline & $\begin{array}{l}0.36^{*} \\
(2.32)\end{array}$ & $\begin{array}{r}-0.85 \\
(-0.98)\end{array}$ & $\begin{array}{r}-0.66 \\
(-0.77)\end{array}$ & $\begin{array}{l}1.62 * \\
(9.46)\end{array}$ & $\begin{array}{l}2.26 * \\
(3.10)\end{array}$ & $\begin{array}{l}2.27 * \\
(3.08)\end{array}$ \\
\hline \multicolumn{7}{|c|}{ Individual Attributes } \\
\hline Household Income & $\begin{array}{l}-0.004^{* *} \\
(-1.82)\end{array}$ & $\begin{array}{l}-0.006 * \\
(-2.70)\end{array}$ & $\begin{array}{l}-0.006 * \\
(-2.79)\end{array}$ & $\begin{array}{l}0.003 \\
(1.27)\end{array}$ & $\begin{array}{l}0.004 * * \\
(1.72)\end{array}$ & $\begin{array}{l}0.004 * * \\
(1.72)\end{array}$ \\
\hline $\begin{array}{l}\text { Member of Conservation } \\
\text { Organization }\end{array}$ & $\begin{array}{l}0.78^{*} \\
(5.40)\end{array}$ & $\begin{array}{l}0.55^{*} \\
(3.36)\end{array}$ & $\begin{array}{l}0.56 * \\
(3.68)\end{array}$ & $\begin{array}{c}-0.54 * \\
(-4.49)\end{array}$ & $\begin{array}{l}-0.36 * \\
(-2.70)\end{array}$ & $\begin{array}{l}-0.36 * \\
(-2.70)\end{array}$ \\
\hline Tourism-Related Job & $\begin{array}{r}0.08 \\
(0.72)\end{array}$ & $\begin{array}{r}-0.09 \\
(-0.73)\end{array}$ & $\begin{array}{r}-0.06 \\
(-0.51)\end{array}$ & $\begin{array}{l}0.51 * \\
(4.87)\end{array}$ & $\begin{array}{l}0.45^{*} \\
(3.96)\end{array}$ & $\begin{array}{l}0.44 * \\
(3.93)\end{array}$ \\
\hline \multicolumn{7}{|c|}{ Community Attributes } \\
\hline County Unemployment Rate & & $\begin{array}{l}-0.12 * \\
(-3.50)\end{array}$ & ${ }^{-0.11 *}$ & & $\begin{array}{l}0.007 \\
(0.26)\end{array}$ & $\begin{array}{l}0.006 \\
(0.20)\end{array}$ \\
\hline $\begin{array}{l}\text { County Travel Expenditures } \\
\text { per Job (Dependence } \\
\text { on Tourism) }\end{array}$ & & $\begin{array}{l}0.00006^{*} \\
(6.47)\end{array}$ & $\begin{array}{r}0.00004^{*} \\
(3.95)\end{array}$ & & $\begin{array}{l}0.00002^{*} \\
(2.22)\end{array}$ & $\begin{array}{l}0.00002 * \\
(2.03)\end{array}$ \\
\hline County Median Income & & $\begin{array}{l}0.08 * \\
(3.11)\end{array}$ & $\begin{array}{l}0.07^{*} \\
(2.79)\end{array}$ & & $\begin{array}{r}-0.03 \\
(-1.55)\end{array}$ & $\begin{array}{r}-0.03 \\
(-1.51)\end{array}$ \\
\hline Population Growth Rate & & & $\begin{array}{l}0.01^{*} \\
(3.18)\end{array}$ & & & $\begin{array}{r}-0.001 \\
(-0.36)\end{array}$ \\
\hline \multicolumn{7}{|c|}{ Thresholds } \\
\hline$\mu 1$ & $\begin{array}{l}1.60^{*} \\
(18.63)\end{array}$ & $\begin{array}{l}1.87^{*} \\
(18.55)\end{array}$ & $\begin{array}{l}1.90^{*} \\
(18.64)\end{array}$ & $\begin{array}{l}0.76^{*} \\
(7.30)\end{array}$ & $\begin{array}{l}0.77^{*} \\
(7.21)\end{array}$ & $\begin{array}{l}0.77^{*} \\
(7.19)\end{array}$ \\
\hline$\mu_{2}$ & & & & ${ }^{11.34} 4^{*}$ & $\begin{array}{l}1.35 * \\
(11.48)\end{array}$ & $\begin{array}{l}1.36 * \\
(11.45)\end{array}$ \\
\hline$\mu 3$ & & & & $\begin{array}{l}2.60 * \\
(20.04)\end{array}$ & $\begin{array}{l}2.64^{*} \\
(19.80)\end{array}$ & $\begin{array}{l}2.64^{*} \\
(19.80)\end{array}$ \\
\hline$x^{2}$ & $41.4^{*}$ & $173.4^{*}$ & $181.9 *$ & $56.2 *$ & $70.8 *$ & $70.9 *$ \\
\hline $\mathbf{n}$ & 461 & 461 & 461 & 460 & 460 & 460 \\
\hline$\%$ Correct Predictions & 52.1 & 68.1 & 67.9 & 44.3 & 45.9 & 44.3 \\
\hline $\ln \mathrm{L}$ & -425.72 & -359.68 & -355.48 & -599.22 & -591.90 & -591.84 \\
\hline Likelihood Ratio Test $^{c}$ & & $132.1 *$ & $140.5^{*}$ & & $14.6^{*}$ & $14.8^{*}$ \\
\hline
\end{tabular}

NOTES: Numbers in parentheses are ratios of the coefficient to its asymptotic standard error.

* Significant at 0.05 level. $\quad$ **Significant at 0.10 level.

Dependent Variable: 3 = Too quickly. 2 = About right. 1 = Too slowly.

bependent Variable: $5=$ Strongly agree. $4=$ Agree. $3=$ Uncertain. $2=$ Disagree, $1=$ Strongly disagree.

cTests hypothesis that community-level slopes are equal to zero. 
TABLE 4

Attitudes Toward Future Tourism Growth and Impacts

\begin{tabular}{|c|c|c|c|c|c|c|}
\hline \multirow{2}{*}{$\begin{array}{l}\text { Variable } \\
\text { Intercept }\end{array}$} & \multicolumn{3}{|c|}{$\begin{array}{l}\text { Question *3 } \\
\text { Tourism should play a major role in the } \\
\text { community's future." }\end{array}$} & \multicolumn{3}{|c|}{$\begin{array}{l}\text { Question } 44 \\
\text { The charecter of the cominumits } \\
\text { should be preserved. }\end{array}$} \\
\hline & $\begin{array}{l}1.77 * \\
(7.52)\end{array}$ & ${ }^{1.50^{* *}}$ & $\begin{array}{l}1.49 * * \\
(1.80)\end{array}$ & $\begin{array}{l}2.57^{*} \\
(9.02)\end{array}$ & $\begin{array}{r}0.88 \\
(1.12)\end{array}$ & $\begin{array}{r}0.83 \\
(1.05)\end{array}$ \\
\hline \multicolumn{7}{|c|}{ Individual Attributes } \\
\hline Household Income & $\begin{array}{l}0.007^{*} \\
(3.25)\end{array}$ & $\begin{array}{l}0.008 * \\
(3.56)\end{array}$ & $\begin{array}{l}0.008 * \\
(3.56)\end{array}$ & $\begin{array}{r}-0.003 \\
(-1.27)\end{array}$ & $\begin{array}{r}-0.004 \\
(-1.60)\end{array}$ & $\begin{array}{l}-0.004 \\
(-1.61)\end{array}$ \\
\hline $\begin{array}{l}\text { Member of Conservation } \\
\text { Organization }\end{array}$ & $\begin{array}{l}-0.68 * \\
(-5.48)\end{array}$ & $(-4.02)$ & $\begin{array}{l}-0.56 * \\
(-4.02)\end{array}$ & $\begin{array}{r}0.15 \\
(1.07)\end{array}$ & $\begin{array}{r}-0.11 \\
(-0.68)\end{array}$ & $\begin{array}{r}-0.11 \\
(-0.70)\end{array}$ \\
\hline Tourism-Related Job & $\begin{array}{l}0.84 * \\
(7.08)\end{array}$ & $\begin{array}{l}0.75^{*} \\
(6.06)\end{array}$ & $\begin{array}{l}0.75 * \\
(6.05)\end{array}$ & $\begin{array}{l}-0.005 \\
(-0.04)\end{array}$ & $\begin{array}{r}0.03 \\
(0.19)\end{array}$ & $\begin{array}{r}0.01 \\
(0.11)\end{array}$ \\
\hline Length of Residence & ${ }^{-0.41 *}$ & $\begin{array}{l}-0.39 * \\
(-2.30)\end{array}$ & $\begin{array}{c}-0.39 * \\
(-2.26)\end{array}$ & $\begin{array}{r}0.05 \\
(0.30)\end{array}$ & $\begin{array}{r}0.03 \\
(0.19)\end{array}$ & $\begin{array}{r}0.03 \\
(0.20)\end{array}$ \\
\hline \multicolumn{7}{|c|}{ Community Attributes } \\
\hline County Unemployment Rate & & $\begin{array}{r}0.02 \\
(0.62)\end{array}$ & $\begin{array}{r}0.02 \\
(0.57)\end{array}$ & & $\begin{array}{r}0.01 \\
(0.38)\end{array}$ & $\begin{array}{l}0.005 \\
(0.17)\end{array}$ \\
\hline $\begin{array}{l}\text { County Travel Expenditures } \\
\text { per Job (Dependence on } \\
\text { Tourism) }\end{array}$ & & $\begin{array}{l}0.00002 * \\
(2.59)\end{array}$ & $\begin{array}{c}0.00003^{*} \\
(2.38)\end{array}$ & & $\begin{array}{c}-0.00009--( \\
(-0.95)\end{array}$ & $\begin{array}{r}.000002 \\
(-0.17)\end{array}$ \\
\hline County Median Income & & $\begin{array}{r}-0.004 \\
(-0.18)\end{array}$ & $\begin{array}{l}-0.004 \\
(-0.15)\end{array}$ & & $\begin{array}{l}0.07 * \\
(3.08)\end{array}$ & $\begin{array}{l}0.08 * \\
(3.20)\end{array}$ \\
\hline Population Growth Rate & & & $\begin{array}{l}-0.001 \\
(-0.26)\end{array}$ & & & $\begin{array}{l}-0.004 \\
(-1.16)\end{array}$ \\
\hline \multicolumn{7}{|c|}{ Thresholds } \\
\hline$\mu_{1}$ & $\begin{array}{l}0.58 * \\
(4.90)\end{array}$ & $\begin{array}{l}0.58 * \\
(4.87)\end{array}$ & $\begin{array}{l}0.57^{*} \\
(4.86)\end{array}$ & $\begin{array}{r}0.37 \\
(2.21)\end{array}$ & $\begin{array}{l}0.39 * \\
(2.17)\end{array}$ & $\begin{array}{l}0.39^{*} \\
(2.16)\end{array}$ \\
\hline$\mu_{2}$ & $\begin{array}{l}0.94 * \\
(7.20)\end{array}$ & $\begin{array}{l}0.94 * \\
(7.13)\end{array}$ & $\begin{array}{l}0.94^{*} \\
(7.12)\end{array}$ & $\begin{array}{r}1.18 \\
(5.67)\end{array}$ & $\begin{array}{l}1.22 * \\
(5.62)\end{array}$ & $\begin{array}{l}1.22 * \\
(5.57)\end{array}$ \\
\hline$\mu_{3}$ & $\begin{array}{l}2.00 * \\
(13.63)\end{array}$ & $\begin{array}{l}2.01 * \\
(13.62)\end{array}$ & $\begin{array}{l}2.01 * \\
(13.62)\end{array}$ & $\begin{array}{r}2.16 \\
(10.15)\end{array}$ & $\begin{array}{c}2.23 \\
(10.00)\end{array}$ & $\begin{array}{l}2.23 * \\
(9.92)\end{array}$ \\
\hline$x^{2}$ & $111.36 *$ & $124.4 *$ & $124.4 *$ & 2.8 & $21.0^{*}$ & $21.0^{*}$ \\
\hline $\mathbf{n}$ & 463 & 463 & 463 & 462 & 462 & 462 \\
\hline$\%$ Correct Predictions & 57.2 & 58.3 & 58.3 & 63.0 & 63.0 & 63.0 \\
\hline $\ln \mathrm{L}$ & -463.70 & -457.20 & -457.16 & -426.75 & -417.64 & -416.92 \\
\hline Likelihood Ratio Test ${ }^{b}$ & & $13.0^{*}$ & $13.1^{*}$ & & $18.2^{*}$ & $19.7 *$ \\
\hline
\end{tabular}

NOTES: Numbers in parentheses are ratios of the coefficient to its asymptotic standard error.

* Significant at 0.05 level.

**Significant at 0.10 level.

'Dependent Variable: 5 = Strongly agree. 4 = Agree. 3 = Uncertain. 2 = Disagree. 1 = Strongly disagree.

Dests hypothesis that community-level slopes are equal to zero. 
tive attitudes toward tourism. In contrast, members of conservation organizations are more likely to say that tourism is growing too quickly. Somewhat surprisingly, individuals with tourism-related jobs are not significantly different from others in their attitudes about tourism growth.

All three community-level factors in the second model are statistically significant indicators of a resident's attitude about tourism growth. As median income in the county increases, or as economic dependence on tourism increases, residents are more likely to say that tourism is growing about right or too quickly. In contrast, residents from counties with relatively higher unemployment rates were more likely to believe that tourism is growing too slowly. These communitylevel results, which conform to a priori expectations, point to the dynamics of community support for tourism development. As community-level income increases or tourism's importance to the local economy increases or unemployment declines, there is less support for additional tourism-based development because the costs are perceived to outweigh the benefits. On the other hand, communities experiencing higher unemployment with lower median incomes and where tourism's share of the local economy is smaller, there is more support for further tourism-based development. This is the situation in many rural communities that look to tourism development as the solution to problems of unemployment and low incomes.

The final model demonstrates that residents are sensitive to the rate of growth in the population; as population growth increases, residents are more likely to say that tourism is growing too quickly. This is consistent with contingency analysis of the same data which showed that a significant proportion of the sample believed that rapid population growth associated with tourism development had adversely affected their community.

Results of the likelihood ratio test, reported in the last line of Table 3, indicate that it is important to consider both individual- and community-level attributes when designing "appropriate" tourism-based development. In particular, note the opposing and statistically significant signs of coefficients for individualand community-level measures of household income. The results suggest that wealthier residents may reap more of the income benefits associated with tourism, whereas wealthier communities as a whole have less positive attitudes toward tourism development because the marginal gains in community income are outweighed by other aspects of negative community-level impacts.

\section{Tourism and the Quality of Life}

The quality of life in rural areas can be affected by tourism development in a variety of ways: increased traffic congestion, strains on community infrastructure, 
increased cost of living, and deteriorating local environmental conditions. In explaining resident attitudes toward the impact of tourism on the quality of life in their community, the individual-level attributes provide more statistically significant results than do the community level attributes (Table 3 ).

Individuals with higher incomes and those holding tourism-related jobs are more likely to strongly agree that tourism increases the quality of life in the community. Members of conservation organizations are less likely to strongly agree that tourism increases the quality of life in the community. Higher income residents may be better placed to take advantage of new economic and leisure opportunities presented by tourism development. In contrast, members of conservation groups appear to give greater weight to the negative impacts of tourism development on quality-of-life parameters.

The only statistically significant community-level explanatory variable was the measure of economic dependence on tourism. Residents from counties with higher economic dependence on tourism are more likely to respond that tourism increases the quality of life in the community. Recall that residents from counties with higher economic dependence on tourism also tend to respond that tourism is growing about right or too quickly. Thus, for counties with well-developed tourism sectors, a threshold level may be approaching (although residents still acknowledge the positive contribution of the tourism sector). ${ }^{11}$

\section{The Role of Tourism in the Community's Future}

Individuals with tourism-related jobs are more likely to strongly agree that tourism should play a major role in the community's future, whereas membership in a conservation organization decreases the probability of such a response (Table 4). These results conform to $a$ priori expectations. The greater an individual's household income, the more likely the individual is to strongly agree with this statement, which is consistent with results presented in Table 3. This was the only model in which length of residence in the community was a statistically significant determinant of respondent attitudes. The greater the proportion of the respondent's life spent in the community, the less likely the individual was to strongly agree that tourism should play a major role in the community's future. Only one community-level attribute was statistically significant: the greater a county's economic dependence on tourism, the more likely residents were to strongly agree that tourism should play a major role in the community's future. 


\section{Preserving the Community's Character}

Unconstrained development of tourism resources in rural areas has the potential to transform a community's character and obscure its heritage. In examining this issue, none of the individual-level attributes provides any statistically significant insights (Table 4). The lack of statistically significant individual-level attributes may be informative in these models. Contingency analysis across groups (business persons, public officials, and members of conservation organizations) found that responses across the three groups were statistically identical. The ordered probit analysis extends the analysis to other dimensions of the respondents, and still finds no statistically significant correlates. These results are possibly due to an underlying consensus across all residents that preserving a community's character is an important goal.

The only statistically significant explanatory variable is a community-level attribute-median county income. It was found that as median income increases (i.e., as communities become more affluent), residents become more concerned about preserving the character of the community. This suggests that communities encounter the classic income-environmental quality trade-off as they develop. ${ }^{12}$

\section{IMPLICATIONS FOR TOURISM AS A REGIONAL DEVELOPMENT STRATEGY}

The results suggest three broad conclusions with implications for tourism as a regional development strategy. First, individual attributes are important determinants of residents' attitudes. In general, members of conservation groups tend to be less supportive of tourism development than business people and public officials. On the other hand, residents involved in the tourism sector and higher income residents tend to be more supportive of tourism development. These results can help planners and policymakers in consensus-building efforts aimed at generating support for a tourism development strategy.

Second, measures of community welfare do influence resident opinions toward the development of tourism resources. Residents are cognizant of the more "public" aspects associated with tourism development, so that planners and policymakers are correct to focus on measures such as unemployment and median income in evaluating whether a community would desire tourism. That is, individual resident's attitudes are important to gauge, but community-level socioeconomic characteristics can also provide insights into the support for, or resistance to, tourism development. 
Third, the results suggest that support for tourism development is dynamic and changing as the goals of rural economic development are achieved. For example, consider a community with high unemployment and low income which engages in tourism development. The models predict that as a successful development plan results in declining unemployment and increasing community income, residents are more likely to respond that tourism is growing too quickly, and thus be more critical of future development. Thus, there does appear to be a threshold level of tourism development that residents are willing to support. In addition, the type of tourism development desired can change over time (Siegel and Jakus 1995). This conclusion is consistent with the finding that communities with higher economic dependence on tourism acknowledge the positive contribution of the tourism sector, but seem to be less supportive of continued tourism development.

\section{CONCLUSION}

The ordered probit analysis presented here is a promising analytical tool that may be used to help planners and policymakers in the design of "appropriate" tourism-based development for a given community. The analysis presented in this study suggests that tourism development must be tailored to fit communityspecific socio-economic conditions because resident attitudes are explained, in part, by community characteristics. Policymakers need to be aware of where the community stands in terms of aggregate measures (population growth, median income, etc.) to initially evaluate support for tourism development. The analysis cannot focus solely on community-level attributes, however, because of the influence of individual factors (income, alignment with a conservation organization, etc). Policymakers can identify the individuals whose support for tourism development is needed-in this study, public officials, business persons and conservation group members-and begin a series of public meetings to devise a sustainable tourism development policy.

\section{ENDNOTES}

1. As Henning (1990) points out: "Hostile or indifferent residents can have a negative impact on visitors. Comprehensive planning considers the potential benefits from tourism development and the potential social and environmental costs of development." 
2. Ordinary least squares is inappropriate for ordered data because the ranking is ordinal in nature, not cardinal. See Greene (1992) for an overview of ordered probit model.

3. The number of thresholds, $\mu_{j}$, estimated for the ordered probit model is $c-2$, where $c$ is the number of ordered responses available to a survey participant.

4. The six counties were the study site of a project that encourages environmentally-benign economic development and involved the Southern Appalachian Man and Biosphere Cooperative, and a consortium of public agencies, including the National Park Service and the Tennessee Valley Authority.

5. The questionnaire and data used in this analysis are available upon request.

6. The actual influence of leaders in shaping development policy depends on a complicated set of relationships between leaders and other residents (Ayres and Potter 1989).

7. This response rate is quite good for a mail survey with a single reminder postcard, and suggests that the topic was timely and important to the populations surveyed.

8. Nonresponse effects may be present, but the survey methodology prevented a formal adjustment for potential effects. We do, however, employ dummy variables to capture differences across the groups.

9. Some respondents (mostly business owners) did not reside in the county for which they responded.

10. Income data were collected as a discrete variable in which respondents were asked to indicate the appropriate income category for the household. A grouped data model (Stewart, 1983) was used to predict income and generate a continuous variable.

11. To investigate the possibility of a threshold, the model was also run using a quadratic term for economic dependence on tourism. The term was not statistically significant.

12. For example, Shaffer (1989) cites a study that found suburban residents from areas with minimal air quality problems and sufficient jobs were very concerned about air quality, whereas central city residents from areas with poor air quality and limited jobs were very concerned about job opportunities.

\section{REFERENCES}

Allen, L. R., P. T. Long, R. R. Perdue, and S. Kieselbach. "The Impact of Tourism Development on Resident's Perceptions of Community Life." Journal of Travel Research 27 (1988): 16-21. 
Ayres, J. S., and H. R. Potter. "Attitudes Toward Community Change: A Comparison Between Rural Leaders and Residents." Journal of the Community Development Society 20 (1989): 1-18.

Feuerstein, H. L. and M. T. Feuerstein. "After the Carnival: Tourism and Community Development." Community Development Journal 27 (1992): 335352.

Frederick, M. "Rural Tourism and Economic Development." Economic Development Quarterly 7 (1993): 215-224.

Fritz, R. G. "Strategic Planning with a System Dynamics Model for Regional Tourism Site Development." Review of Regional Studies 19 (1989): 57-71.

Gibson, L.A. "The Potential for Tourism Development in Nonmetropolitan Area." in D. L. Barkley (ed.) Economic Adaption: Alternatives for Nonmetropolitan Areas. Boulder CO: Westview Press, 1993.

Greene, W. H. Econometric Analysis. New York: MacMillan, 1992.

Henning, S. A. Measuring Leadership Perceptions of Recreation and Tourism Development in Rural Coastal Zones. Mississippi State, MS: Southern Rural Development Center, Mississippi State University. SRDC Report No. 133. September 1990.

Lankford, S. V. and D. R. Howard. "Developing a Tourism Attitude Scale." Annals of Tourism Research. 21 (1994): 121-139.

Long, P. T., R. R. Perdue, and L. Allen. "Rural Resident Tourism Perceptions and Attitudes By Community Level of Tourism." Journal of Travel Research 28 (1990): 3-9.

Luloff, A. E., J. C. Bridger, A. R. Graefe, M. Saylor, K. Martin, and R. Gitelson. "Assessing Rural Tourism Efforts in the United States." Annals of Tourism Research 21(1994): 46-64.

Peine, J. D., and H. G. Welch. Sustainable Development Strategies for Communities with Tourism-Based Economies in the Southern Appalachian Highlands. Gatlinburg, TN: Southern Appalachian Man and the Biosphere Cooperative, Great Smoky Mountains National Park, Uplands Field Research Laboratory. September 1990.

Raitz, K. B., and R. Ulack. Appalachia: A Regional Geography. Boulder CO: Westview Press, 1984.

Shaffer, R. Community Economics: Economic Structure and Change in Smaller Communities. Ames, IA: Iowa State Press, 1989.

Siegel, P. B., and P. M. Jakus. "Tourism as a Sustainable Rural Development Strategy: Finding Consensus in Resident Attitudes." Southern Rural Sociology 11 (1): 17-41.

Stewart, M. "On Least Squares Estimation When the Dependent Variable is Grouped." Review of Economic Studies 50 (1983): 737-753. 
U.S. Travel Data Center. Impact of Travel on State Economies, 1990. Washington, D.C., 1992. 